RAD Conference Proceedings, vol. 2, pp. 269-275, 2017

www.rad-proceedings.org

\title{
THE EFFECT OF PLANT DISEASES ON HYPERSPECTRAL LEAF REFLECTANCE AND BIOPHYSICAL PARAMETERS
}

\author{
Dora Krezhova ${ }^{1}$, Kalinka Velichkova ${ }^{2}$, Nikolai Petrov3, Svetla Maneva 3 \\ ${ }^{1}$ Space Research and Technology Institute, Bulgarian Academy of Sciences, Sofia, Bulgaria \\ ${ }^{2}$ University of Mining and Geology "St. Ivan Rilski”, Sofia, Bulgaria \\ 3Institute of Soil Science, Agrotechnologies and Plant Protection "Nikola Pushkarov", \\ Bulgarian Agricultural Academy, Sofia, Bulgaria
}

\begin{abstract}
Contemporary remote sensing techniques have acquired new and more advanced applications in environmental and ecological researches. Hyperspectral remote sensing data provide significant advancement in understanding the subtle changes in biophysical and biochemical parameters of the plants and their responses to adverse environmental conditions. In this study, a remote sensing method based on hyperspectral measurements of leaf reflectance was used to extract information on the effect of biotic stress (two viral infections) on young potato plants. The reflectance data were collected by means of a portable fiber-optics spectrometer in the visible and nearinfrared spectral ranges $(400-1100 \mathrm{~nm})$. To translate the hyperspectral data into information about plant biophysical and biochemical variables, an empirical-statistical approach was applied based on Student's t-test, first derivative, and serological analyses. The changes in some important biophysical parameters such as color and spectral signature of plants, chlorophyll absorption characteristics, moisture content, etc., were analyzed. The results showed that the variations in the chlorophyll content, leaf structure, and water content dominate in the reflectance variance in the green, red, and near-infrared spectral ranges. Comparative analysis was performed between the results from the leaf spectral reflectance and serological test (DAS-ELISA) for the presence and degree of the viral infections.
\end{abstract}

Key words: Hyperspectral remote sensing, leaf spectral reflectance, viral infection, Potato Virus Y (PVY), Potato Leaf Roll Virus (PLRV)

DOI: $10.21175 / \operatorname{RadProc} .2017 .55$

\section{INTRODUCTION}

Biophysical parameters have been identified as the most important physical properties of terrestrial surfaces due to their specific roles in geospherebiosphere-atmosphere interactions. Vegetation takes a very significant part in these interactions because of its unique role in global climate change. Vegetation has also become an important source of food and energy. Its amount controls the partitioning of incoming solar energy into sensible and latent heat fluxes, and, consequently, changes in vegetation amount will result in long-term changes in the local and global climates, which in turn will affect the vegetation growth as a feedback [1].

Plant diseases affect plants with the potential to cause devastating, economic, social, and ecological losses [2], [3]. The spatial and temporal monitoring of plant ecosystems provides important information about the responses of plants to the changing environmental conditions and their physiological status. Some diseases do not have any visible symptoms associated with them, or those appear only when it is too late to act. In those cases, normally some kind of sophisticated analysis, usually by means of powerful microscopes, is necessary. Most diseases generate some kind of manifestation in the visible (VIS) spectrum. In other cases, however, some of the signs can only be detected in parts of the electromagnetic spectrum that are not visible to humans. Therefore, a common approach in such cases is the use of remote sensing (RS) techniques [4].

Hyperspectral RS method based on the measurements of leaf reflectance in hundreds of narrow spectral bands provides the possibility for accurately studying and objectively assessing plants' spectral properties and estimating plant health and crop yields [5], [6]. Nowadays, this method allows presymptomatic monitoring of changes in the physiological status of plants with a high spectral resolution and before the appearance of visible symptoms [7], [8].

The reflectance and absorption features in narrow bands are related to specific characteristics of plants such as biochemical composition (chlorophyll, Chl, and nitrogen content, pigments, dry matter, etc.) [9], color, leaf structure, water content [10], and plant physiological status [11]. Leaf Chl content is the key variable which affects the photosynthetic capacity and

*dkrezhova@stil.bas.bg 
productivity [12], [13]. The Chl content and a fraction of absorbed photosynthetically active radiation are widely applied in environmental studies concerning growth monitoring, stress detection, and yield estimation [14]-[16].

The general shape of reflectance and transmittance curves for green leaves is similar for all species. It is controlled by absorption features of specific molecules and the cellular structure of the leaf tissue [17]. When foliage changes through phenological aging or when plants undergo environmental stresses or diseases, leaf Chl content is observed to decline. This results in an increase in the reflectance and transmittance over the visible spectrum [18]-[20]. These relationships were usually established empirically or directly estimated, using physical models.

Potato is one of the most important and popular crops with a significant economic importance for humanity. In terms of human consumption, potato (Solanum tuberosum L.) is the third important crop in the world, after rice and wheat. Potatoes can be infected by many different viruses (at least 40) that can negatively affect the harvest and the tuber quality [21]. Viral diseases can often be diagnosed by mosaic forms on leaves, stunting of the plant, leaf and tuber malformations, Fig. 1. Some of the most common viruses that attack the potato are: Potato virus Y (PVY), Potato leaf roll virus (PLRV) [22]-[24], Potato virus S (PVS), Potato virus X (PVX), Potato mop top virus (PMTV), Tobacco rattle virus (TRV) [25].

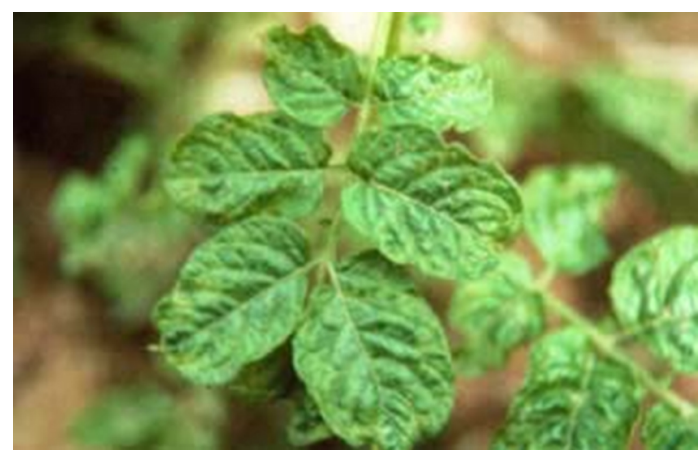

Figure 1. Severe PVY symptoms in potato leaves

In this study, a remote sensing method based on hyperspectral measurements of leaf reflectance in the VIS and near-infrared (NIR) spectral ranges was applied to extract information about the effect of biotic stress (viral infections) on young potato plants. Plants from early potato cultivars Jelly and Marabel, resistant to viral infections, were infected with PVY and PLRV potato viruses respectively, and were subjected to preliminary screening for the presence of viral infections at an early stage without visible symptoms on the leaves.

\section{MATERIALS AND METHODS}

\subsection{Plant material}

Six pots with potato plants cultivar Jelly and another six - with potato plants cultivar Marabel were subjected to the analyses. In each of the pots were grown four plants. Three pots from each potato cultivar were used as a healthy (control) group. The plants were grown in greenhouse conditions $\left(24^{\circ} \mathrm{C}\right.$, air humidity $45 \%$, photoperiod of $16 / 8 \mathrm{~h}$ ). The potato was from the potato collection of the Institute of Soil Sciences, Agrotechnologies and Plant Protection (ISSAPP).

\subsection{Viruses for inoculation}

PVY strain N/NTN (PVYN/NTN) group and Potato Leaf Roll Virus (PLRV), obtained from the virus collection of ISSAPP, were used.

\subsection{Mechanical inoculation of plants with PVY and PLRV}

Plants from three pots from each cultivar were inoculated with PVY and PLRV, respectively, by Noordam [26]. Prior to inoculation, the plants were placed in a room with low light (shading), sprinkled with water and the leaves were dusted with carborundum 400-600 meshes. One gram of the symptomatic plant foliage was homogenized in $1 \mathrm{ml}$ of potassium sodium phosphate buffer with $\mathrm{pH}$ 8.0, cooled to $4 \mathrm{C}^{\mathrm{O}}$. The buffer contained $0.2 \% \mathrm{Na}_{2} \mathrm{SO}_{3}$ and $0.2 \%$ ascorbic acid. Inoculations were performed by gently rubbing the leaves with this homogenate. After 3-5 minutes, the plants were washed with water. Inoculated plants were daily observed for virus symptoms.

\subsection{Spectral reflectance measurements}

Fresh detached leaves (2-3) from each potato plant of two cultivars Jelly and Marabel, resistant to viral infections, were used for the investigations. The plants were divided into two groups - infected (Jelly with PVY and Marabel with PLRV) and non-infected (healthy), treated as control. The measurements were conducted on the $3^{\text {th }}$ day after the inoculation. The plants infected with two viruses developed without any signs of disease on the aerial parts.

Spectral measurements of the leaf reflectance of healthy and infected plants were carried out by means of a portable fiber-optics spectrometer USB2000 (Ocean Optics, USA) [27] in laboratory on an experimental setup in dark room [28]. Hyperspectral data were collected in the VIS and NIR spectral ranges $(400-1100 \mathrm{~nm})$ with a sampling interval of $0.3 \mathrm{~nm}$ and a spectral resolution of $1.5 \mathrm{~nm}$. The measuring entrance lens was located at the end of the optical fiber and was directed perpendicular to the measured leaf surfaces. The light source used was a halogen lamp providing homogeneous illumination of the leaf surfaces. In the beginning of each measurement the source light reflected from a diffuse reflectance standard (WS1) was registered. The objective and the $\mathrm{WS} 1$ standard (located also perpendicular to the entrance lens) were fixed on a special adjustable tripod-born platform, which provided an accurate relative positioning of each equipment component. The entrance lens field-of-view $\left(25^{\circ}\right)$ ensures measurement of the leave reflectance and standard screen radiance of an area (pixel) with a diameter of $1 \mathrm{~cm}$ from a distance of $10 \mathrm{~cm}$. Leaf reflectance was registered from up to 30 leaf areas for each plant group. 
Spectral reflectance (SR) is a property used to quantify the spectral signatures of the leaves and is described as a ratio of the intensity of reflected light to the illuminated light in dependence on wavelength. Changes in the absorption of incident light allow the identification of plant health and stress. The spectral reflectance characteristics (SRC) of the investigated plants were determined as the ratio between the radiation reflected from the leaves and the one reflected from the diffuse reflectance standard (Eq. 1). Specialized software was used for data acquisition and processing.

$$
R(\lambda)=[E R(\lambda) / E I(\lambda)] \times 100,
$$

where: $R(\lambda)$ - spectral reflectance, $E_{R}(\lambda)$ - reflected light, $\operatorname{Er}(\lambda)$ - illuminated light, reflected from the diffuse reflectance standard for each wavelength in VIS $(450-700 \mathrm{~nm})$ and NIR $(700-850 \mathrm{~nm})$ spectral ranges.

\subsection{Data analyses}

Data analyses were performed in the spectral range 450-850 $\mathrm{nm}$ where the differences in SRC were more significant. The Student's t-test and first derivative analyses were applied for the determination of the statistical significance of differences between the sets of the values of the SRC of healthy (control) and infected plants as well as the position of the inflection points in the red edge region. Analyses were carried out in four spectral ranges most informative for the investigated plants: green (520-580 nm, maximal reflectivity of green vegetation), red (640-68o $\mathrm{nm}$, maximal chlorophyll absorption), red edge (680-720 nm, maximal slope of the reflectance spectra) and the NIR $(720-770 \mathrm{~nm})$. The statistical significance of the differences between SRC of control and infected leaves was examined in ten wavelengths $\left(\lambda_{1}=475.22 \mathrm{~nm}, \lambda_{2}=\right.$ $489.37 \mathrm{~nm}, \lambda_{3}=524.29 \mathrm{~nm}, \lambda_{4}=539.65 \mathrm{~nm}, \lambda_{5}=$ $552.82 \mathrm{~nm}, \lambda_{6}=667.33 \mathrm{~nm}, \lambda_{7}=703.56 \mathrm{~nm}, \lambda_{8}=719.31$ $\mathrm{nm}, \lambda_{9}=724.31 \mathrm{~nm}$, and $\lambda_{10}=758.39 \mathrm{~nm}$ ) chosen to be disposed uniformly over the four spectral ranges.

\subsection{Serological diagnostic test DAS-ELISA}

The analyses for the presence of viruses were conducted by the method of Clark and Adams [29]. We used a commercial kit of LOEWE Biochemica $\mathrm{GmbH}$, Sauerlach, Germany. ELISA plates were loaded with antiserum (IgG) for PVY/PLRV, with dilutions (according to the instructions of the manufacturer) in $0.05 \mathrm{M}$ carbonate buffer. The samples were incubated for 4 hours at $37{ }^{\circ} \mathrm{C}$, and the unbound components were washed out with PBS-T buffer for $5 \mathrm{~min}$. All samples were grounded in extraction buffer containing 1\% PVP (polyvinyl pyrrolidone) in a ratio of 1:10. The plates were incubated at $4{ }^{\circ} \mathrm{C}$ for 16 hours. Following the third wash step alkaline-phosphatase conjugate for PVY/PLRV was added and the plates were incubated for 4 hours at $37{ }^{\circ} \mathrm{C}$. The substrate used was pnitrophenyl phosphate (p-nitrophenyl phosphate, Sigma) in diethanolamine buffer ( $\mathrm{pH} \mathrm{9.8)} \mathrm{at} \mathrm{a} \mathrm{ratio} \mathrm{of}$ $1 \mathrm{mg} / \mathrm{ml}$. The reaction proceeded in the light at room temperature and was stopped with $3 \mathrm{~N} \mathrm{NaOH}$. The adsorption of the color reaction was measured at multifunctional detector (DTX 880) at a wavelength of $405 \mathrm{~nm}$. The positive samples had optical density (OD) over the threshold (Cut-off) which is three times the value of the negative control.

\section{RESULTS AND DISCUSSION}

The averaged SRC over all measurements (up to 30 areas) of control and infected with PVY leaves from potato plants cultivar Jelly are shown in Fig. 2. It is seen that the differences between the values of SRC of infected and healthy leaves are not significant. According to the literature, this cultivar is resistant to PVY [30]. Small differences are observed in the spectral range 530-690 $\mathrm{nm}$ where the values of SRC of the infected plants are increased. It is due to the decrease of the Chl content in the infected leaves that affects the amount of the absorbed portion of the illuminated light. In NIR spectral range the SRC values of infected leaves are lower than control, which indicates that some changes in cell structures have appeared as a result of the viral inoculation.

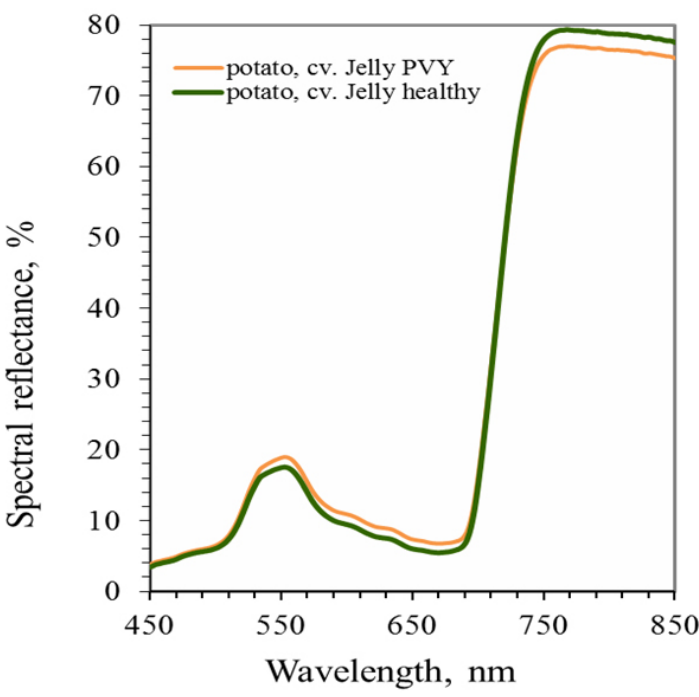

Figure 2. Averaged spectral reflectance characteristics of control potato plants, cultivar Jelly, and those infected with $\mathrm{PVY}$, on the $3^{\text {rd }}$ day after the inoculation

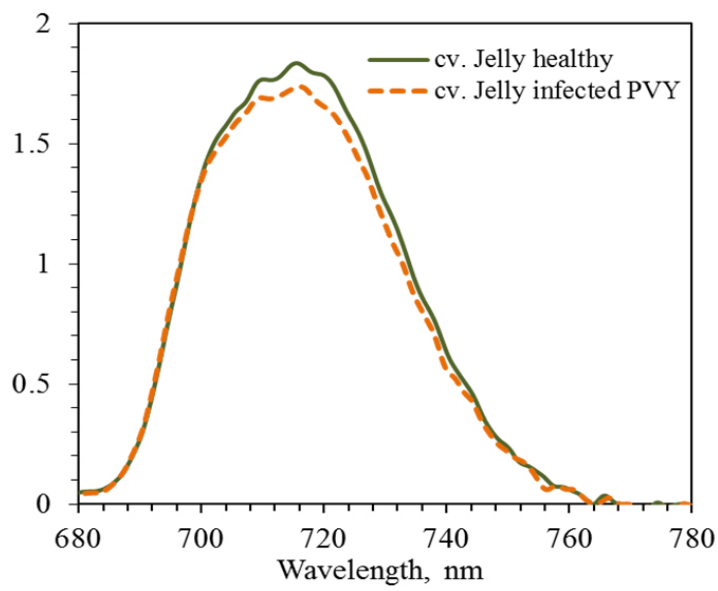

Figure 3. Maximums of the first derivatives on the averaged SRC of healthy potato plants, cultivar Jelly, and those infected with PVY 
To assess the position of the red edge, first derivative analysis was applied to the averaged SRC, Fig. 3. In this case, a shift of the main maximum on the derivative of SRC of the infected plants against the control has not appeared. This is an indicator that potato plants are not diseased yet.

The results from statistical analyses are set in Table 1 . In the first column of the table, $\mathrm{R}_{\mathrm{i}} / \mathrm{R}_{\mathrm{ic}}$ $(\mathrm{i}=1, \ldots, 10)$ designates that the data sets of the spectral reflectance of the infected $\left(\mathrm{R}_{\mathrm{i}}\right)$ and the control $\left(\mathrm{R}_{\mathrm{ic}}\right)$ leaves are compared at the ten above-listed wavelengths. For potato plants cultivar Jelly the differences between means of sets of the SRC values of control and infected leaves are statistically significant in eight wavelengths. Statistically non-significant are the differences in two wavelengths in NIR range.

Fig. 4 shows the SRC, averaged over all measurements (up to 30), of control leaves from potato cultivar Marabel and those infected with PLRV. The values of SRC of the infected leaves are very close to those of the control in the VIS spectral range. More significant are the differences in NIR spectral range.

Table 1. Means and p-values of the Student's t-test of SRC of control and infected potato leaves, cultivars Jelly and Marabel

\begin{tabular}{|c|c|c|c|c|c|c|}
\hline \multirow{3}{*}{$\begin{array}{c}\text { Pairs } \\
\text { compared }\end{array}$} & \multicolumn{3}{|c|}{ Jelly } & \multicolumn{3}{|c|}{ Marabel } \\
\hline & Healthy & \multirow{2}{*}{$\mathrm{p}<$} & Infected & Healthy & \multirow{2}{*}{$\mathrm{p}<$} & Infected \\
\hline & mean & & mean & mean & & mean \\
\hline$R_{1} / R_{1 c}$ & 4.96 & $* * *$ & 5.31 & 4.17 & $* * *$ & 4.78 \\
\hline$R_{2} / R_{2 c}$ & 5.61 & $* * *$ & 5.96 & 4.91 & $* * *$ & 5.51 \\
\hline$R_{3} / R_{3 c}$ & 12.62 & $* * *$ & 13.54 & 10.87 & $* *$ & 11.49 \\
\hline$R_{4} / R_{4 c}$ & 16.75 & $* * *$ & 18.00 & 14.62 & $* *$ & 15.20 \\
\hline$R_{5} / R_{5 c}$ & 17.55 & $* * *$ & 18.98 & 15.41 & $*$ & 15.98 \\
\hline$R_{6} / R_{6 c}$ & 5.49 & $* * *$ & 6.78 & 5.41 & $* *$ & 5.95 \\
\hline$R_{7} / R_{7 \mathrm{c}}$ & 20.03 & $* * *$ & 21.25 & 17.04 & $*$ & 17.62 \\
\hline$R_{8} / R_{8 c}$ & 47.52 & ns & 47.55 & 41.00 & $* *$ & 42.02 \\
\hline$R_{9} / R_{9 c}$ & 56.11 & ns & 55.56 & 48.63 & *** & 49.83 \\
\hline$R_{10} / R_{10 c}$ & 79.01 & $* * *$ & 76.72 & 69.25 & $* * *$ & 70.82 \\
\hline
\end{tabular}

ns - no statistical significance; ${ }^{*}-\mathrm{p}<0.05 ;{ }^{* *}-\mathrm{p}<0.01 ;{ }^{* * *}-\mathrm{p}<0.001$

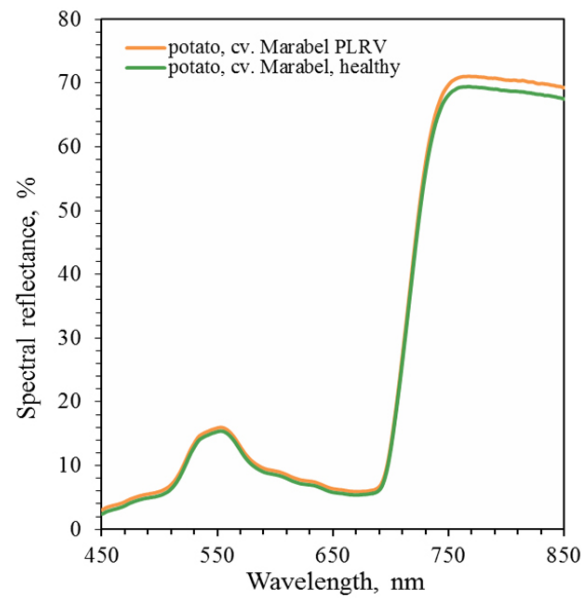

Figure 4. Averaged spectral reflectance characteristics of control potato plants, cultivar Marabel, and those infected with PLRV, on the $3^{\text {rd }}$ day after the inoculation

To assess the red edge positions, first derivative analysis was applied to the averaged SRC of healthy and infected leaves, Fig. 5. A shift to lowest wavelength of the derivative maximum of SRC of infected leaves against the control is not observed.

The results from Student's t-test (Table 1) applied on the SRC of potato plants cultivar Marabel show that the differences are statistically significant in all investigated wavelengths. This result indicates that the decrease of the Chl content, reflected in increasing of SRC values in the spectral range $450-690 \mathrm{~nm}$, and changes in cell strictures of the infected leaves are more weakly manifested in comparison with the leaves infected with PVY. These plants are also not diseased.

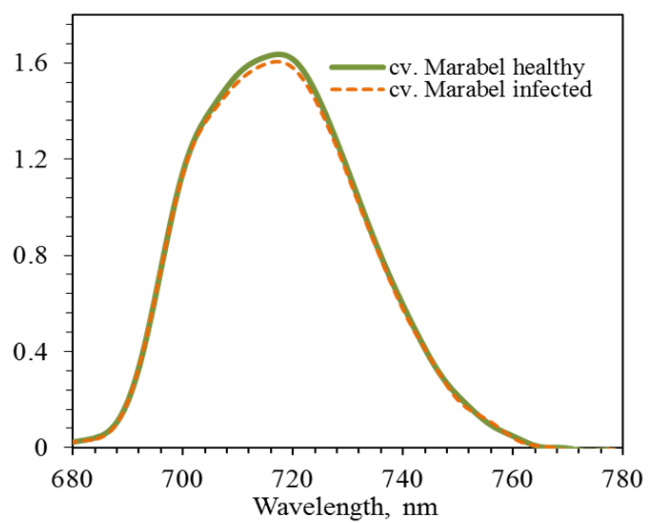

Figure 5. Maximums of the first derivatives on the averaged SRC of healthy potato plants, cultivar Marabel and those infected with PLRV

The serological test DAS-ELISA was applied separately on the leaf samples from each pot of healthy and infected plants. The results given in Fig. 6 show a presence of viruses in the infected groups of leaves from both potato cultivars (Jelly 1, 2, 3 and Marabel 1, $2,3)$. All samples showing extinction values (optical density, OD) exceeding three times the negative control $(\mathrm{K}-)$, i. e. over the threshold (Cut-off), were considered as virus-positive or virus carriers. $(\mathrm{K}+)$ is positive control from the kit and (B-) is negative control buffer. The control groups present extinction values near to the negative control. The extinction values for Jelly cultivar are higher than those for cultivar Marabel, which is in correspondence to the changes accrued in averaged SRC of infected plants. 


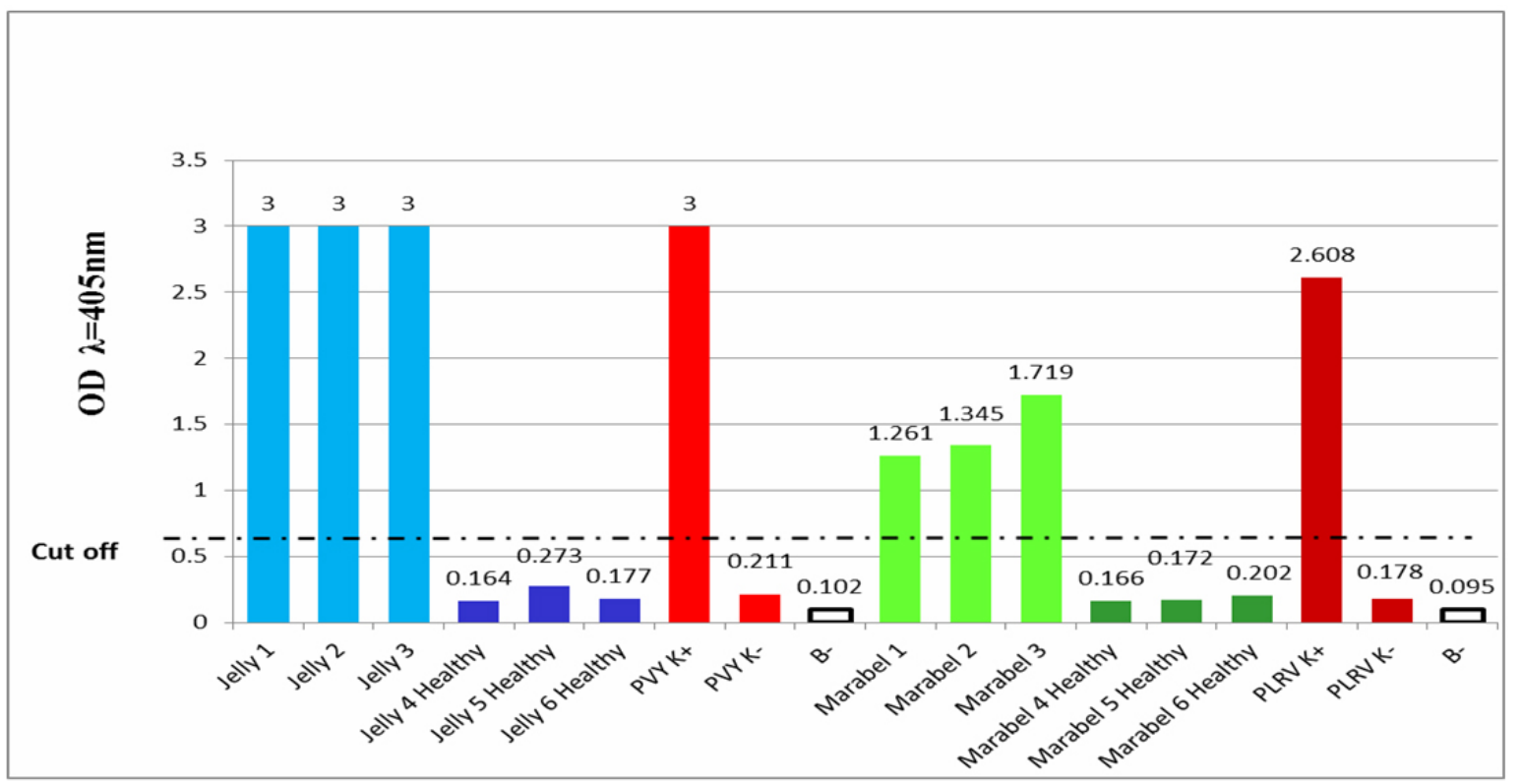

Figure 6. Results from DAS-ELISA test on the leaf samples from two potato cultivars - Jelly and Marabel

Fig. 7 illustrates the spectral behavior (SRC of 25 measured areas) of the leaves from three pots of potato plants, cultivar Jelly, infected with PVY. It is seen that the differences between them are not very pronounced.

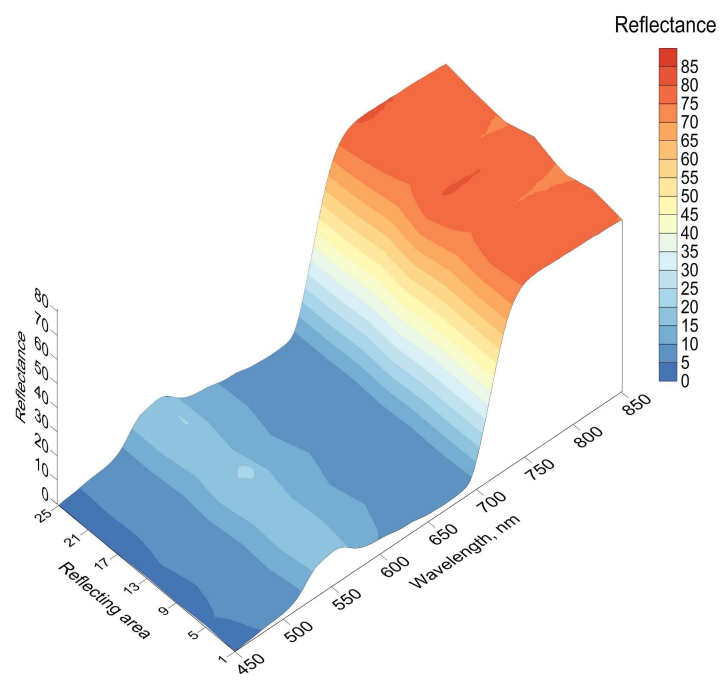

Figure 7. Averaged spectral reflectance characteristics of 25 measured areas from the three pots with infected plants cultivar Jelly

\section{CONCLUSIONS}

Remote sensing method based on hyperspectral measurements of leaf reflectance was applied for detection of viral infections, caused by two viruses Potato Virus Y (PVY) and Potato Leaf Roll Virus (PLRV), on two potato cultivars (Jelly and Marabel). The plants were without visible symptoms on the leaves and stems. According to literature the cultivars investigated should be resistant to potato viruses. The results from serological DAS-ELISA test showed the presence of viruses in leaves of two inoculated plant groups. Spectral reflectance analyses established that weakly pronounced changes in SRC of these two groups have appeared in spectral range 500-690 $\mathrm{nm}$ and in NIR region. These changes are related in general to changes in the leaf biophysical parameters such as color, leaf structure, water content, and plant physiological status. The changes usually correspond also to the variations in the biochemical composition of the leaves (chlorophyll and pigment contents, dry matter, etc.). Statistical (Student t-test) analyses of the reflectance data demonstrated that the differences between SRC of control and infected leaves were statistically significant in all investigated spectral regions. The first derivative analyses assessed no changes in the red edge position of infected plants that is an indicator for physiological status of the plants. Regardless of the presence of the viruses the plants were not damaged and diseased.

This research demonstrated the efficiency of the applied remote-sensing method of spectral reflectance to enable pre-symptomatic monitoring (early detection) of changes in the physiological status and biophysical properties of the plants non-destructively. Using leaf reflectance as the method for crop monitoring would allow alleviating plant stress at an early stage, thus avoiding irreversible damage and substantially reducing yield losses.

\section{REFERENCES}

1. J. Qi, F. Cabot, M. S. Moran, G. Dedieu, "Biophysical Parameter Estimations Using Multidirectional Spectral Measurements," Remote Sens. Environ., vol. 54, no. 1, pp. 71-83, Oct. 1995 .

DOI: 10.1016/0034-4257(95)00102-7 
2. P. Jordano, "Chasing Ecological Interactions," PLoS Biol., vol. 14, no. 9, pp. e1002559-1 - e1002559-4, Sep. 2016.

DOI: 10.1371/journal.pbio.1002559

PMid: 27631692

PMCid: PMC5025190

3. J.P. T. Valkonen, "Viruses: Economical losses and biotechnological potential," in Potato Biology and Biotechnology, D. Vreugdenhil, J. Bradshaw, C. Gebhardt, F. Govers, D. K. L. Mackerron, M. A. Taylor, H. A. Ross, Eds., San Diego (CA), USA: Elsevier Academic Press, 2007, ch. 28, pp. 619-641.

DOI: 10.1016/B978-044451018-1/50070-1

4. K. Usha, B. Singh, "Potential applications of remote sensing in horticulture - A review," Sci. Horticul., vol. 153, pp. 71-83, Apr. 2013. DOI: 10.1016/j.scienta.2013.01.008

5. M. Meroni, M. Rossini, R. Colombo, "Characterization of leaf physiology using reflectance and fluorescence hyperspectral measurements," in Remote Sensing Optical observation of vegetation properties, F. Maselli, M. Menenti, P. A. Brivio Eds., Trivandrum, India: Research Signpost, 2010, pp. 165-187.

6. S. Sankaran, A. Mishra, R. Ehsani, C. Davis, "A review of advanced techniques for detecting plant diseases," Comput. Electron. Agric., vol. 72, no. 1, pp. 1-13, Jun. 2010.

DOI: 10.1016/j.compag.2010.02.007

7. D. D. Krezhova, N. M. Petrov, S. N. Maneva, "Hyperspectral remote sensing applications for monitoring and stress detection in cultural plants: viral infections in tobacco plants," in Proc. of Remote Sensing for Agriculture, Ecosystems, and Hydrology Conf., Edinburgh, UK, 2012, pp. 24-27. DOI: $10.1117 / 12.974722$

8. Z. Ni, Z. Liu, H. Huo, Z. H. Li, F. Nerry, Q. Wang, X. Li, "Early Water Stress Detection Using Leaf-Level Measurements of Chlorophyll Fluorescence and Temperature Data," Remote Sens., vol. 7, no. 3, pp. 3232-3249, Mar. 2015.

DOI: $10.3390 / \mathrm{rs} 70303232$

9. G. R. Mahajan, R. N. Sahoo, R. N. Pandey, V. K. Gupta, D. Kumar, "Using hyperspectral remote sensing techniques to monitor nitrogen, phosphorus, sulphur and potassium in wheat (Triticum aestivum L.)," Precision Agric., vol. 15, no. 2, pp. 499 - 522, Oct. 2014. DOI: 10.1007/s11119-014-9348-7

10. C. M. Champagne, K. Staenz, A. Bannari, H. Menairn, J. C. Deguise, "Validation of a hyperspectral curvefitting model for the estimation of plant water content of agricultural canopies," Remote Sensing Environ., vol. 87, no. 2-3, pp. 148-160, Oct. 2003. DOI: $10.1016 /$ So034-4257(03)o0137-8

11. M. Prabhakar, Y. G. Prasad, M. Thirupathi, G. Sreedevi, B. Dharajothi, B. Venkateswarlu, "Use of ground based hyperspectral remote sensing for detection of stress in cotton caused by leafhopper (Hemiptera: Cicadellidae)," Comput. Electron. Agric., vol. 79, no. 2, pp. 189-198, Nov. 2011.

DOI: 10.1016/j.compag.2011.09.012

12. A. A. Gitelson, U. Gritz, M. N. Merzlyak, "Relationships between leaf chlorophyll content and spectra reflectance and algorithms for non-destructive chlorophyll assessment in higher plant leaves," J. Plant Physiol., vol. 160, no. 3, pp. 271-282, Mar. 2003. DOI: $10.1078 / 0176-1617-00887$ PMid: 12749084

13. G. A. Carter, B. A. Spiering, "Optical properties of intact leaves for estimating chlorophyll content," J. Environ. Quality, vol. 31, no. 5, Sep-Oct. pp. 1424-1432, 2002. DOI: $10.2134 /$ jeq2002.1424 PMid: 12371158
14. I. B. Strachan, E. Pattey, J. B. Boisvert, "Impact of nitrogen and environmental conditions on corn as detected by hyperspectral reflectance," Remote Sensing Environ., vol. 80, no. 2, pp. 213-224, May 2002. DOI: 10.1016/So034-4257(01)oo299-1

15. D. Krezhova, "Spectral remote sensing of the responses of soybean plants to environmental stresses," in Soybean - Genetics and Novel Techniques for Yield Enhancement, D. Krezhova, Ed., Rijeka, Croatia: InTech, 2011, ch. 11, pp. 215-256.

DOI: $10.5772 / 24741$

16. S. Pradhan, K. K. Bandyopadhyay et al., "Predicting wheat grain and biomass yield using canopy reflectance of booting stage," J. Indian Soc. Remote Sensing, vol. 42, no. 4, pp. $711-718$, Dec. 2014.

DOI: $10.1007 / \mathrm{s} 12524-0140372-\mathrm{x}$

17. C. S. T. Daughtry, C. L. Walthall, M. S. Kim, E. B. Colstoun, J. E. McMurtrey, "Estimating corn leaf chlorophyll concentration from leaf and canopy reflectance," Remote Sens. Environ., vol. 74, no. 2, pp. 229-239, Nov. 2000. DOI: 10.1016/Soo34-4257(00)00113-9

18. D. Krezhova, S. Maneva, N. Petrov, "Application of remote sensing technique for preservation of plant ecosystems," in Proc. RAD 2015 Conference, Budva, Montenegro, 2015, pp. 285-290.

Retrieved from:

http://www.radconference.org/helper/download.php?file=../pdf/Proce edings\%20RAD\%202015.pdf

Retrieved on: Jan. 15, 2017

19. S. J. Goetz, "Recent advances in remote sensing of biophysical variables. An overview of the special issue," Remote Sensing of Environment, vol. 79, no. 2-3, pp. 145-146, Feb. 2002

DOI: 10.1016/Soo34-4257(01)00268-1

20. D. Krezhova, E. Kirova, "Hyperspectral remote sensing of the impact of environmental stresses on nitrogen fixing soybean plants (Glycine $\max$ L.)," in IEEE proceedings of $5^{\text {th }}$ International Conference of RAST, Istanbul, Turkey, 2011, pp. 172-177. DOI: $10.1109 /$ rast.2011.5966816

21. S. B. Johnson, "Potato Diseases Caused by PVY and PLRV," Bulletin, University of Maine, Orono (ME), USA, 1999.

Retrieved from: https://extension.umaine.edu/publications/2492e/ Retrieved on: Dec. 23, 2016

22. Н. Петров, Д. Христова, К. Хайнце, П. Вилингман, Г. Адам, "Идентифициране на вируса, причинител на некротични пръстеновидни петна по клубените на картофите в България," Растениевъдни науки, т. 45. стр. 407 - 411, 2008. (N. Petrov, D. Hristova C. Heinze, P. Willingman, G. Adam, "Identification of the virus, causing necrotic ring spots on potato tubers in Bulgaria," Plant Science, vol. 45, pp. 407-411, 2008.) Retrieved from:

https://www.researchgate.net/publication/260244501 Identification of the virus causing necrotic ring spots on potato tubers in Bulgaria

Retrieved on: Dec. 23, 2016

23. N. Petrov, V. Lyubenova, "Variability in P1 gene region of Potato virus $\mathrm{Y}$ isolates and its effect on potato crops," in Proc. Conf. The Man and the Universe, Smolyan, Bulgaria, 2011, pp. 671-677.

Retrieved from: https://www.researchgate.net/publication/260244852 variability in p1 gene region of potato virus $\mathrm{y} i$ solates and its effect on potato crops

Retrieved on: Jan. 13, 2017

24. Н. Петров, "Картофен вирус Y (Potato Virus - PVY) по културни видове от сем. Solenaceae,” докторска дисертация, ИПАЗР “Н. Пушкаров”, София, България, 2012. (N. Petrov, "Potato virus Y (PVY) in 
crop species from the family Solanaceae," ISSAPP "N. Pushkarov", Sofia, Bulgaria, 2012.)

Retrieved from:

http://www.iss-

poushkarov.org/N\%20Petrov/Avtoreferat_N\%20Petrov .pdf

Retrieved on: Jan. 23, 2017

25. B. Dikova, "Tobacco rattle virus (TRV) transmission by sugarbeet seeds," Biotechnology \& Biotechnological Equipment, vol. 19, no. 2, pp. 87-90, 2005.

DOI: $10.1080 / 13102818.2005 .10817196$

26. D. Noordam, Identification of plant viruses: methods and experiments, Wageningen, The Netherlands: Centre for Agricultural Publishing and Documentation, 1973.

27. USB2Ooo+ Data Sheet, Ocean Optics, Dunedin (FL), USA.

Retrieved from:

https://oceanoptics.com/wp-content/uploads/OEM-

Data-Sheet-USB2000-.pdf

Retrieved on: Jan. 23, 2017
28. D. Krezhova, T. Yanev et al., "Method for detecting stress induced changes in leaf spectral reflectance," Compt. Rend. Acad. Bulg. Sci., vol. 58, no. 5, pp. 517 $522,2005$.

29. M. Clark, A. Adams, "Characteristics of the microplate method of enzyme linked immunosorbent assay for the detection of plant viruses," J. Gen. Virol., vol. 34, no. 3, pp. 475-483, Mar. 1977.

DOI: $10.1099 / 0022-1317-34-3-475$

PMid: 323416

30. C. L. Bădărău, S. C. Chiru, F. Damşa, A. Mărculescu, "Behavior of several potato varieties with different starch content to potato tuber necrotic ringspot disease," Forest. Wood Ind. Agric. Food Eng., vol. 8, no. 57, 2015.

Retrieved from:

http://webbut.unitbv.ro/BU2015/Series\%20II/BULET IN\%20I\%20PDF/o6 BADARAU.pdf

Retrieved on: Jan. 24, 2017 